\title{
Jeremiah Horrocks's Lancashire
}

\author{
John K. Walton \\ Department of History, University of Central Lancashire, Preston PR1 2HE, UK \\ (email: jkwalton@uclan.ac.uk)
}

\begin{abstract}
This paper sets Jeremiah Horrocks and Much Hoole in the context of Lancashire society on the eve of the English Civil War. It focuses on the complexities of what it was to be a "Puritan" in an environment where religious labels and conflicts mattered a great deal; it examines the economic circumstances of county and locality at the time, pointing out the extent to which (despite widespread and deep poverty) the county's merchants were looking outwards to London, northern Europe and beyond; and it emphasizes that even in the apparently remote and rustic location of Much Hoole it was possible for Horrocks to sustain a scientific correspondence and to keep in touch with, and make his contribution to, developments on a much wider stage.
\end{abstract}

This contribution is intended to complement Allan Chapman's plenary lecture by developing the local and Lancashire dimension to Jeremiah Horrocks's astronomical activities at Much Hoole, less than three years before the outbreak of the great Civil War in 1642, which culminated in the execution of Charles I in 1649 and ushered in Britain's only period of republican government, which lasted until the Restoration in 1660 (see Chapman 1994, to which this paper runs in parallel). Some of the earliest skirmishes of that long and highly significant conflict took place in Lancashire, and the county was unusual in the extent to which it combined a serious, doctrinaire and influential Puritan presence in and around Manchester, in the area where the region's famous textile industries were already beginning to develop, with an area in the west (the coastal plains to the west and south-west of Preston, in the Hundreds of West Derby and Amounderness) where Roman Catholicism survived strongly, especially among the landed gentry (Walker 1939; Haigh 1975).

The religious dimension of the Civil War is often highlighted in the literature, with the Puritans as the staunchest supporters of Parliament pitted against the Catholics as the most determined (though sometimes problematic) allies of the King (Broxap 1910). It is therefore highly relevant to begin by looking at the question of Horrocks's religious affiliation, especially as the apparently straightforward label of "Puritan" that was fixed to him by Victorian biographers and commentators has been hard to shake off. As an illustration, the Guardian of 5 June 2004 referred to Horrocks simply as a "20-year-old Puritan" (with the implication that he really was a very serious young man) even after interviewing Chapman himself, who is very sceptical about the application of this label to the first recorder of the Transit of Venus (Marston 2004, pp. 18-21, is more supportive of the idea of Horrocks as Puritan, though aware of the contemporary flexibility of the term). Placing Horrocks in the context of place and time lends further weight to Chapman's scepticism, and enables us to take it further than the very limited direct biographical evidence allows.

In the first place, we should emphasize the elasticity with which the term "Puritan" might be applied in the Lancashire of the 1630s. The core concept does involve a strong, serious Protestantism that rejected ceremonial and fripperies in divine service, sometimes to the extent of iconoclasm. It prioritised careful listening to assiduously prepared sermons over mere attendance at ceremonial services, and at its core was the believers' 
commitment to exploring their relationship with God and finding out whether they were to be saved or damned according to the divine plan. At an extreme it could embrace Calvinist doctrines of predestination, but their concentration on the fate of the individual soul did not prevent strong Puritans from aspiring to be their brothers' and sisters' keepers, with a commitment to suppressing excessive merriment and immoral behaviour which might involve (for example) the suppression of alehouses, dancing and popular festivities (Wrightson 1974; Poole 2002). Prioritising the individual conscience sometimes also led to challenges to established hierarchies when they seemed to behave in ungodly ways, and Lancashire not only contained Puritan supporters of Parliament against the ungodly Crown, but also opponents of the authority of bishops, so that the area around Manchester in the mid-seventeenth century saw the formation of an alternative Presbyterian church organisation in which ministers were elected by godly members of the congregation rather than being nominated by bishops, colleges, wealthy laymen or the Crown (Halley 1869, Vol. 1, Chapter 4). This embrace of a very limited form of church democracy should be set alongside the well-established (but much debated) association of Puritanism with the development of trade and the "rise of capitalism", and with relative freedom of secular scientific enquiry (as opposed to dangerous pursuits like astrology). It might be tempting to see this as particularly important in the case of Horrocks (Walton 1987, Chapter 3; Richardson 1969). But the actual use of the label "Puritan" in preCivil War Lancashire, especially as a term of abuse deployed by opponents and enemies, went far beyond this core stereotype. It could be applied to anyone who seemed to take religion seriously, read the Bible and attended sermons, even if they also drank, hunted and played bowls, as at least one "Puritan" cleric did. John Angier, a Puritan minister on any definition, was capable of decrying a perceived culture of overwork as denying his parishioners the necessary time to attend to religious duties, an inversion of the orthodoxy about the Puritan work ethic. Lay people with little or no formal schooling could be quite capable of discussing biblical texts and precepts in alehouses, in Lancashire villages, although we do not know whether this applied to Much Hoole (Richardson 1969, p. 84; Heywood 1937; Sachse 1938).

As Chapman makes clear, we know little about Horrocks's actual religious affiliations, but it seems quite possible that contemporaries, especially in Much Hoole, might have regarded him as a Puritan, at least on the less exacting of these definitions. He was, after all, a serious scholar and gave his mind to his books and apparatus, in a place where such concerns would normally be non-existent. We should remember that to be at all convincing as a Puritan it was necessary to be literate to be able to access and interpret the Bible, even though there are reports of prodigious feats of memory as regards sermons and Biblical passages in what was still a predominantly oral culture (for an example see Richardson 1969, p. 102). Reading was taught before writing in what schools there were, which were attended by only about $10 \%$ of children (on one definition); but it was a minority accomplishment at this time, almost vanishingly so among the lower orders: $64 \%$ of a sample of tradesmen, $86 \%$ of husbandmen, $94 \%$ of servants and labourers, and $98 \%$ of women in a Lancashire sample were unable to sign their name, and therefore, in the overwhelming majority of cases, to have the cultural capital for religious reading, speculation and discussion (Rogers 1975b; Walton 1987, Chapter 3).

As we might expect under these conditions, and in a firmly hierarchical society, active Puritanism was most visible among the gentry and the emergent early capitalists who organised local manufacture and linked Lancashire up with external markets, especially in London, Ireland and northern Europe; but it had ramifications among the 'middling sort of people' of craftsmen, artisans and yeoman farmers who, according to some interpretations, made up the backbone of Parliamentary support in the Civil War, and a leavening 
of genuine interest among some of the lower orders (Manning 1976). As we shall see, the Stones brothers, who built Carr House in Much Hoole, where Horrocks observed the transit, for their locally-based farmer and landowner brother, might seem to fit squarely into this pattern, as a London haberdasher and an Amsterdam merchant; but they defy simplistic assumptions by showing no direct evidence for or against Puritan leanings of their own (Marston 2004, pp. 13, 20-1). Most such people emerged from the upper yeomanry or the younger sons of the gentry, a level of social distinction that required far less wealth to sustain it in Lancashire than was the case further south, and a level not far removed from Horrocks's own social origins, despite the romantic assumptions about his alleged poverty that are current in the older literature (Blackwood 1978; Marston 2004, pp. 7 and 15, n. 24).

The limited evidence available on Horrocks's life suggests that he would have come into contact with plenty of Puritan influences. Toxteth, near Liverpool, where he was born in 1619, had originally been settled by Puritans from the Bolton area, which chimes in exactly with the available evidence on Horrocks's family, including the unsubstantiated suggestion of a Bolton connection (Richardson 1969, p. 96, refers to Alexander Horrocks, who shared a Cambridge education with Jeremiah, as 'the puritan pastor of Deane', near Bolton, in the 1620s and 1630s; but no connection can be substantiated); and Liverpool Corporation was early in endowing Puritan "lectureships" to provide an island of active Protestantism in the surrounding sea of West Lancashire Catholicism (Walton 1987, Chapter 3). The family connection with watch-making, part of an emerging complex of craft and metalworking industries in the Liverpool area at this time, which was to make its own contribution to the early Industrial Revolution more than a century later, also fits the pattern of Puritan engagement with trade beyond the locality and access to external ideas; and the fact that Horrocks's family had access to sufficient resources to send him to Cambridge for three years suggests a comfortable background among the upper levels of the 'middling sort' (Marston 2004, pp. 7-8; Langton 1979). We have no direct evidence of the sort of 'sponsored mobility' initiated by a patron that often propelled promising boys from the local grammar schools to Oxford or Cambridge at this time, although it would be tempting to assume that the Alexander Horrocks who attended an unspecified college at Cambridge University in the generation before Jeremiah might have set an extended family precedent and otherwise smoothed the path in some way; and the lack of external patronage for Horrocks's astronomical work would tend to support the assumption that there was enough money in the family to support him in his scholarly pursuits, no doubt with the goal of an eventual career in the Church (Richardson 1969; Stone 1966). Once at Cambridge he would certainly have encountered current Puritan views at close hand, not least in his own college, Emmanuel (Richardson 1969). And in Much Hoole, on his return to his native county, he would probably have stood out very distinctively from the society around him, unless there were popular Puritans and 'sermon-gadders' in the hamlet who have remained hidden from the historian's view.

We do not know much about Much Hoole in the first half of the seventeenth century. Although it was situated just outside the Catholic strongholds of Warrington Deanery and West Derby Hundred, it was part of that Lancashire that the Puritans of the Manchester area regarded as a 'dark corner of the land', where what strong formal religious influences there were would be at least as much Catholic as Protestant, and where older beliefs survived alongside a Christianity that might receive little doctrinal understanding or assent among the poor (Haigh 1975; Richardson 1969; Poole 2002). This was, notoriously, a county of sprawling parishes, ill-endowed chapels and poorly-paid, sometimes incompetent incumbents, although the standard had been raised considerably since the late sixteenth century (Haigh 1975; Richardson 1969). Moreover, the poor in the 
Lancashire of the second quarter of the seventeenth century really were poor: the memory of the famine years of 1623-4 and of the epidemics (apparently including bubonic plague) of 1630 would still be present, and there were more to come in the troubled 1640s. Famine had threatened in the Rochdale area as recently as 1638 (Rogers 1975a; Appleby 1978; Walton 1987, Chapter 2). Much Hoole was on the edge of the Catholic heartland of barely accessible mosses and marshland that was south-west Lancashire, around Croston and Martin Mere, where flooding regularly made the churches inaccessible (Walton 1987, Chapter 2; Walker 1939). It was on an old route to a crossing point on the River Ribble, and the county town of Preston was accessible, as was Liverpool to the south-west; but it was unusual among Lancashire villages in having no resident gentry at all, like neighbouring Little Hoole, Longton and Tarleton, and even the neighbouring towns were of no great size (Blackwood 1978). On the best recent estimates, Preston in 1664 had a population of 1890 , making it the third largest town in Lancashire south of the banks of the River Ribble, while Liverpool's great days were still a century in the future. Its main trade was still coastal and with Ireland, and a population of 1273 left it seventh in the same league table. Preston at least drew in the Lancashire gentry for Assizes and Quarter Sessions, and was the market centre for a wide area, at which opinions could be exchanged and business transacted beyond the bounds of the locality; but the Much Hoole village community has the hallmarks of a small and isolated place on any definition (Stobart 2003; Walton 2000, pp. 123-4).

Lancashire in the second quarter of the seventeenth century was, indeed, an impoverished county, although its position near the bottom of national league tables of wealth based on taxation returns needs to be qualified by awareness that it was probably easier to evade tax or get away with artificially low property valuations in areas like this, where the weakness of central government was indicated by (among other things) the very extent of Roman Catholic survival in face of ostensibly penal discrimination (Walton 1987, Chapters 1-2). Within the broader setting, the area around Much Hoole was particularly undeveloped, lying as it did at a distance from the emergent textile industries of the Manchester district or the coal mines of south-west and south central Lancashire (Langton 1979). In a context of substantial population expansion across the county between 1563 and 1664, Leyland Deanery, in which Much Hoole was situated, saw growth of only $14 \%$ during this period, compared with $89 \%$ for Manchester Deanery, the main centre of the emergent textile industries, and a surprising $121 \%$ for the bucolic and peripheral Amounderness Deanery, north of the River Ribble and mainly west of Preston (Phillips \& Smith 1994, p. 9). Much of the population growth elsewhere in the county merely deepened poverty and vulnerability to crisis by putting pressure on limited resources; but the contrast between the Much Hoole area and the neighbouring deaneries suggests a failure to share in developments that were occurring nearby.

Horrocks's horizons, however, were not bounded by his locality. Not only had he been brought up near the emergent (though still tiny and isolated) port of Liverpool, he had spent the years between 1632 and 1635 far from his roots, at a Cambridge college that was noted for its Puritan leanings, and he was capable of sustaining correspondence with like-minded people at a distance, even from this apparently isolated corner of Lancashire (Walton 1987, Chapters 2-3; Marston 2004, pp. 8-9). If he was indeed employed by the Stones family at Carr House, as Chapman surmises, he was in touch with the wider currents of economic growth that are associated with Lancashire's links with London and overseas trade: the currents along which new Protestant ideas also flowed, nourishing Lancashire Puritanism; and Horrocks's contacts with William Crabtree of Salford bring him into a similar orbit (Willan 1980). As Chapman points out, the Stones family endowed a font and provided sacramental plate for Much Hoole church, which shows 
that they were not Puritans on the narrow core definition cited above, although Marston argues that the items in question were sufficiently plain and lacking in ostentation for this not to rule out adhesion to a version of Puritanism, or at least to preclude any accusations of High Church leanings in those who commissioned them (Marston 2004, p. 21). The descriptions of 'Thomas Stones of London, haberdasher, and Andrew Stones of Amsterdam, merchant', who paid for the construction of Carr House for their brother, reveal direct contacts between this part of Lancashire and the burgeoning economy of northern Europe, forming part of a wider pattern whereby Lancashire merchants who had made good in the metropolis and beyond endowed schools, churches and lectureships in their home county in this period (Jordan 1962). Horrocks's Salford correspondent and fellow astronomer, William Crabtree, was also part of this culture as a cloth merchant with metropolitan and international contacts. A lot of this activity, but not all of it, had Puritan associations, and some of its scientific dimensions crossed the religious divide between Protestant and Catholic which in other circumstances, and only three years later, might be regarded as the defining ingredient in Civil War allegiances in the county. According to Charles Webster there was also a Carr House connection with the antiquarian Christopher Towneley, a junior member of the Catholic family of Towneley Hall near Burnley who had astronomical interests. Towneley seems to have facilitated correspondence between Horrocks, Crabtree and three other young northern astronomers across Lancashire and Yorkshire (Webster 1966). Awareness of such networks across the county and beyond makes Much Hoole seem less of a bucolic backwater, and brings out the extent to which a leavening of Lancashire society was responding and contributing to the intellectual ferment of the outside world on the eve of the Scientific Revolution. One of the morals of this story is that you patronise the provinces at your peril.

This paper has demonstrated that we can add extra dimensions to the Horrocks story by placing it in the context of locality and county, and of the religious, cultural and economic currents, complexities and conflicts of the time. It also shows that, despite its bucolic setting and apparent isolation from the main currents of European thought, Much Hoole was not an outrageously improbable place from which to observe the Transit of Venus in 1639.

\section{References}

Appleby, A.B. 1978 Famine in Tudor and Stuart England (Liverpool: Liverpool University Press)

Blackwood, B.G. 1978, The Lancashire Gentry and the Great Rebellion (Manchester: Chetham Society)

Broxap, E. 1910 The Great Civil War in Lancashire (Manchester: Manchester University Press) Chapman, A. 1994, Jeremiah Horrocks and Much Hoole

Haigh, C. 1975, Reformation and Resistance in Tudor Lancashire (Cambridge: Cambridge University Press)

Halley, R. 1869, Lancashire: its Puritanism and Nonconformity (Manchester: Tubbs and Brook, 2 vols.)

Heywood, O. 1937, (ed. E. Broxap), Oliver Heywood's Life of John Angier of Denton (Manchester: Chetham Society)

Jordan, W.K. 1962, The Social Institutions of Lancashire: a Study of the Changing Patterns of Aspiration in Lancashire 1480-1660 (Manchester: Chetham Society)

Langton, J. 1979 Geographical Change and the Industrial Revolution (Cambridge: Cambridge University Press)

Manning, B. 1976 The English People and the English Revolution (London: Heinemann Educational)

Marston, P. 2004 Jeremiah Horrocks: Young Genius and First Venus Transit Observer (Preston: University of Central Lancashire) 
Phillips, C.B., \& J. Smith 1994 Lancashire and Cheshire since AD 1540 (London: Longman,)

Poole, R. (ed.) 2002 The Lancashire Witches: histories and stories (Manchester: Manchester University Press)

Richardson, R.C. 1969 Puritanism in North-West England (Manchester: Manchester University Press)

Rogers, C.D. 1975a The Lancashire Famine of 1623 (Manchester: Manchester University ExtraMural Department)

Rogers, C.D. 1975b 'The Development of a Teaching Profession in England, 1574-1700, with special reference to Lancashire', Ph.D. thesis, University of Manchester

Sachse, W.L. (ed.) 1938 The Diary of Roger Lowe (London: Longman)

Stobart, J. 2003 The First Industrial Region: North-West England 1700-60 (Manchester: Manchester University Press)

Stone, L. 1966 'Social Mobility in England 1500-1700', Past and Present 37

Walker, F.X. 1939 Historical Geography of Southwest Lancashire before the Industrial Revolution (Manchester: Chetham Society)

Walton, J.K. 1987 Lancashire: a Social History 1558-1939 (Manchester: Manchester University Press)

Walton, J.K. 2000 'North', in P. Clark (ed.), The Cambridge Urban History of Britain, Vol. 2 (Cambridge: Cambridge University Press), pp. 111-31

Webster, C. 1966 'Richard Towneley (1629-1707), the Towneley group and seventeenth-century science', Transactions of the Historic Society of Lancashire and Cheshire 118, pp. 51-76

Willan, T.S. 1980 Elizabethan Manchester (Manchester: Chetham Society)

Wrightson, K. 1974 'The Puritan Reformation of Manners, with Special Reference to Lancashire and Essex', unpublished Ph.D. thesis, University of Cambridge

\section{Discussion}

STEVE DiCK: Speaking of economic development, is there any relationship between our Jeremiah Horrocks, and the famous but much later Horrocks cotton industry in this area, which I was reading about yesterday in the museum.

John WaLton: My answer is that I don't know, but it would be interesting to find out.

Allan Chapman: His name, Horrocks, might actually be a modified version of the name for some kind of ...I think it was a kind of ox indigenous in medieval Lancashire; the Orrock was some kind of big brute this might be the origin of "Horrocks" ...

John Walton: He probably was 19 stone and 6-feet tall. The Victorians sometimes spelled his name with an " $\mathrm{x}$ " instead of "cks"; I am not sure what the origin of that was. 


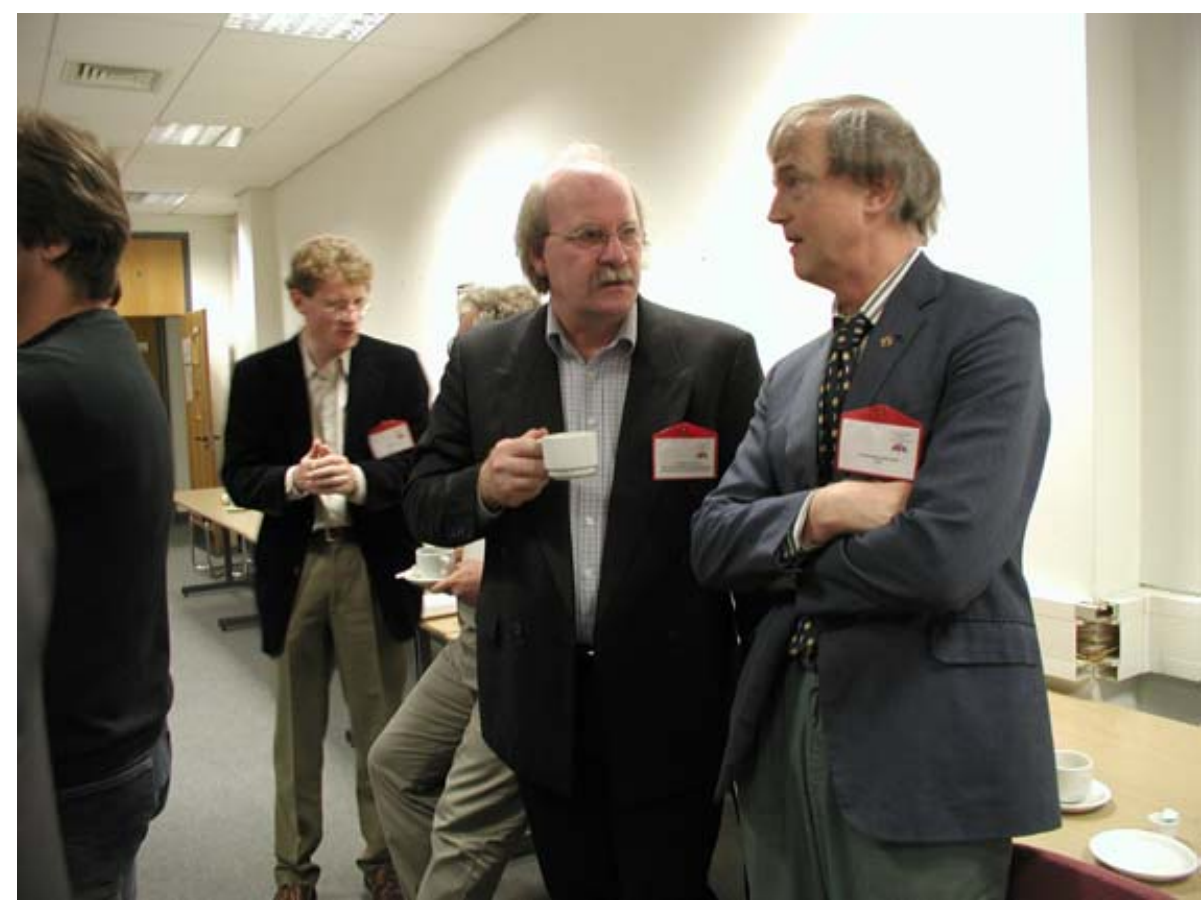

Robert van Gent and Nick Kollerstrom

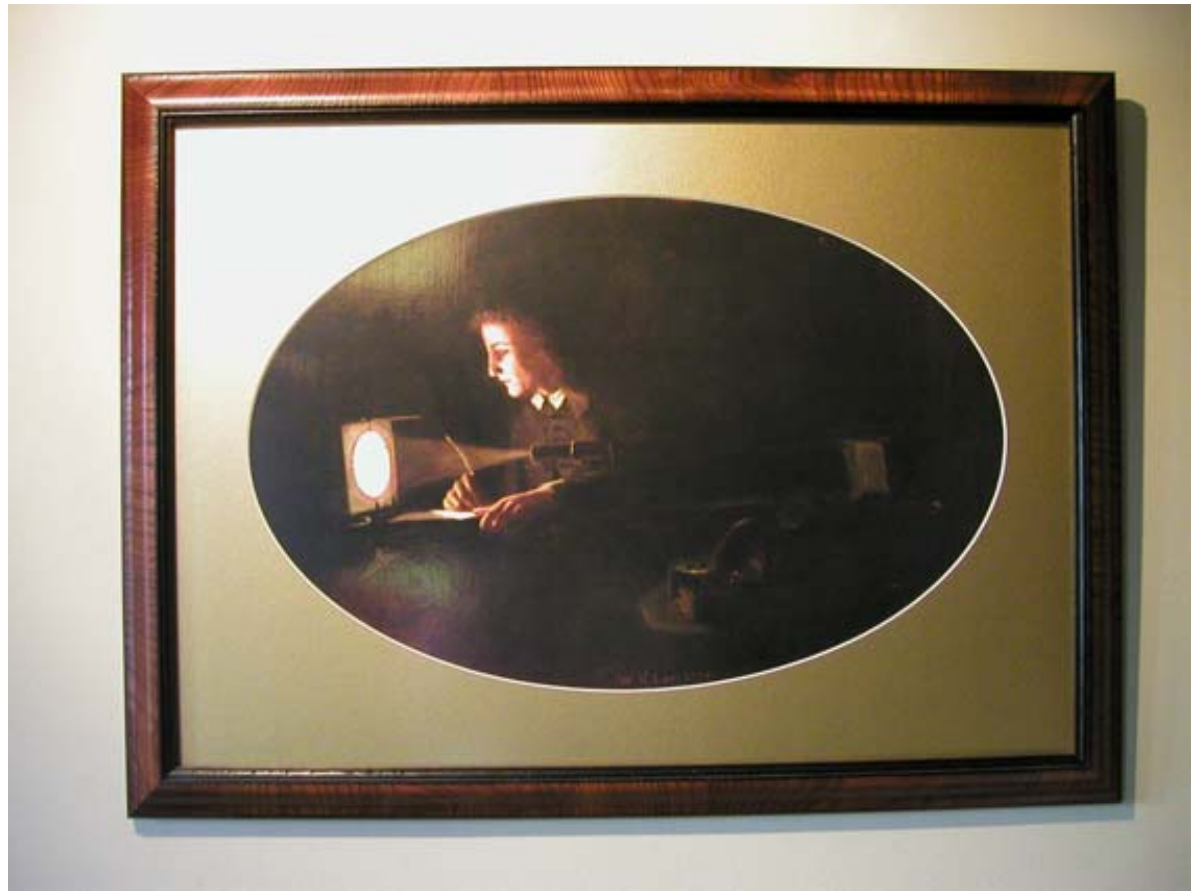

Jeremiah Horrocks as imagined by J.W. Lavender in 1903. This copy hangs in Carr House; the original is in Astley Hall Museum and Art Gallery, Chorley, Lancashire. 